SOCIAL SCIENCES

\title{
Evidence on the use of internet for businesses by MSEs in a Developing Country. The Indonesian case
}

\author{
TULUS T.H. TAMBUNAN
}

\begin{abstract}
This study aims to examine the development of Indonesian micro and small enterprises (MSEs) in utilizing the internet for their businesses. This is a descriptive study in nature, which analyses secondary data on MSMEs. It also reviews key literature on the use of ICT by MSMEs in developing countries. It shows that MSMEs, dominated by MSEs, have been the main player in Indonesian domestic economic activities as they accounted for more than 90 per cent of all firms and contributed to more than 50 per cent of gross domestic product (GDP). But, only a small fraction of total MSEs in Indonesia that utilize the internet for business, and the intensity of internet usage by MSEs varies by province and type of business. This is the first macro-level study ever conducted in Indonesia on the use of internet by MSEs based on national data from 2016 Economic Census conducted. Thus, findings of this study may add new empirical evidence to the literature on the utilization of ICT by MSMEs in developing countries.
\end{abstract}

Key words: Micro, small and medium enterprises (MSMEs), micro and small enterprises (MSEs), internet, information and communication technology (ICT), e-commerce.

\section{INTRODUCTION}

It is undeniable that information and communication technology (ICT) has changed many things in the business; it not only has changed the way businesses communicate to each other or deal with their customers, distributors and suppliers, but also through digital marketing or e-commerce it has also changes the way they promote and sell their products or purchase their raw materials. Digital Marketing has now become the trend in targeting both current and prospective customers. Most people now have daily access to the internet; via computers, laptops or smart phones. Social media is one of the best channels of online marketing, and Instagram is one of the fastest growing platforms available today. More and more businesses are eager to establish a strong presence on this network and encourage their prospects' engagement. To be able to survive in this new business environment all companies including MSEs are pushed to adopt this technology. Soon or later, MSEs which not adopt this new technology and business practice will be displaced by their competitors and abandoned by their customers.

Governments in many countries give considerable attention to the utilization of ICT, particularly the adoption of e-commerce, by MSMEs through issuing policies and regulations to assist them to adopt this technology. In Indonesia, in the past few years the government has taken many measures to encourage or to support MSMEs, particularly MSEs, to use ICT in running their business. The measures include 
providing trainings for MSEs in utilizing such as Facebook, Instagram and other application systems, and to create own websites to promote and market their goods and services; creating a special web portal (SMESCO Trade) by the Ministry of Cooperatives and SMEs that all MSMES can use it for marketing their products; and issuing various regulations to provide a sense of security for business actors in utilizing ICT such as e-commerce for marketing and internet banking for financial transactions.

The purpose of this paper is to examine recent development of MSEs in utilizing the internet in Indonesia. More specifically, it aims to address the following three research questions. First, how many MSEs in Indonesia that use the internet for their businesses? Second, is the intensity of internet usage by MSEs different between types of business and regions within Indonesia? Third, is the profit or income earned by MSES that use the internet greater than that earned by MSEs which do not use it?

Methodologically, this paper is based on a review of key literature on the internet usage by MSMEs mainly in developing countries and a descriptive analysis of secondary data from two sources: data on MSMEs in Indonesia for the period 1997-2017 from the Ministry of Cooperative and SME, and data on the internet usage by MSEs in Indonesia from the National Agency of Statistics (Indonesia's Economic Census 2016). The paper also reviews key literature on the utilization of ICT by MSMEs in developing countries.

\section{DEFINITIONS OF MSMES}

In Indonesia, the definition of MSMEs is set in the Law Number 20, 2008 on MSMEs. In Article 1 in Chapter I (general provisions) of the Law, it is stated that microenterprises (MIE) is a productive business independently owned by an individual person or a business entity fulfilling the criteria of MIE as stipulated in the Law. Small enterprises (SE) is a stand-alone productive economic enterprise undertaken by an individual person or a business entity which is not a subsidiary or not a branch of a company owned, controlled, or becomes part, either directly or indirectly, of medium enterprises (ME) or large enterprise (LE) that meets the SE criteria as stated in the Act. While ME is a stand-alone productive economic enterprise undertaken by an individual person or a business entity that is not a subsidiary or not a branch of a company owned, controlled, or becomes part, directly or indirectly, of MIE, SE or LE that meets the criteria of ME as stipulated in the Act.

In this law, the criteria used to define MSMEs as set forth in Article 6 are net asset value or asset value excluding land and building of business premises, or annual sales. Under these criteria, MIE is a business unit with an asset value of at most Rp 50 million, or with annual sales of maximum Rp 300 million; SE is a business unit with an asset value of more than Rp 50 million up to a maximum of Rp 500 million, or having annual sales of more than $\mathrm{Rp}$ 300 million up to a maximum of Rp 2.5 billion; and ME is a company with a net worth value of more than Rp 500 million up to a maximum of Rp 10 billion, or have annual sales of over Rp 2.5 billion to a maximum of Rp 50 billion.

Alternatively, the Indonesian Central Bureau of Statistics (BPS) uses the number of workers as a measure to differentiate the scale of business between MIE, SE, ME and LE. MIE is a business unit with permanent worker up to 4 people; SE between 5 to 19 workers; and ME from 20 to 99 people. Companies with a workforce of more than 99 people are categorized as LE. 


\section{Key characteritics of MSMEs}

MSMES are not only different from LEs, but within the MSMEs group itself there is a characteristic difference between MIES, SEs and MEs in some aspects that can be easily observed daily in Indonesia. These aspects include the sector in which they operate (formal versus informal), the organizational and management systems applied in the business, the nature of employment within the enterprise, the market orientation, the economic and social profile of the owner, and the technology used including information technology degree of mechanism in the production process (Table I). Understanding the differences in these aspects between MIEs, SES and MEs is indeed important to understand the differences between the three subgroups of MSMEs in performance, such as output growth rates, productivity or efficiency, quality of product, competitiveness, share in gross domestic product (GDP) and exports, and also including the degree of internet usage.

\section{Development of MSMEs}

One characteristic of the Indonesian economy is that economic activities are dominated by MSMEs; although the ratio of MSMEs to LEs varies across economic sectors. For example in the mining sector, particularly in oil, gas and coal, where there are many LEs, including foreign companies, the ratio is lower than in other sectors such as trade, manufacturing industry and agriculture. According to official time series data issued by the State Ministry of Cooperatives

Table I. Key characteristics of MIE, SE, and ME.

\begin{tabular}{|c|c|c|c|c|}
\hline No & Aspect & MIE & SE & ME \\
\hline 1 & Formality & $\begin{array}{c}\text { Degree of informality is } \\
\text { high }\end{array}$ & $\begin{array}{c}\text { Degree of informality is } \\
\text { lower }\end{array}$ & $\begin{array}{l}\text { All are operated formally (i.e. } \\
\text { registered and paid taxes) }\end{array}$ \\
\hline 2 & $\begin{array}{l}\text { Organisation } \\
\& \\
\text { management }\end{array}$ & Primitive/tradisional & $\begin{array}{l}\text { Many are non-primitive } \\
\text { units with modern } \\
\text { management systems }\end{array}$ & $\begin{array}{c}\text { All have formal } \\
\text { organisational structure } \\
\text { with modern management } \\
\text { systems }\end{array}$ \\
\hline 3 & Workers used & $\begin{array}{l}\text { In general, they use } \\
\text { unpaid family members }\end{array}$ & $\begin{array}{c}\text { In general they use wage- } \\
\text { paid employees }\end{array}$ & $\begin{array}{l}\text { All use wage-paid } \\
\text { employees }\end{array}$ \\
\hline 4 & $\begin{array}{l}\text { Production } \\
\text { process }\end{array}$ & Tradisional/manually & $\begin{array}{l}\text { Many are highly } \\
\text { mechanized }\end{array}$ & $\begin{array}{c}\text { Degree of mechanization is } \\
\text { much higher }\end{array}$ \\
\hline 5 & $\begin{array}{l}\text { Market } \\
\text { orientation }\end{array}$ & $\begin{array}{c}\text { Most are very local } \\
\text { oriented; served local low } \\
\text { income } \\
\text { Households }\end{array}$ & $\begin{array}{l}\text { Local, national and/or } \\
\text { export }\end{array}$ & National and/or export \\
\hline 6 & $\begin{array}{l}\text { Economic \& } \\
\text { social profile } \\
\text { of } \\
\text { the owner }\end{array}$ & $\begin{array}{c}\text { Non-/low educated and } \\
\text { poor }\end{array}$ & $\begin{array}{l}\text { Many are well educated and } \\
\text { from non-poor families }\end{array}$ & $\begin{array}{l}\text { Most are well-educated } \\
\text { and from medium to high- } \\
\text { income families. }\end{array}$ \\
\hline 7 & $\begin{array}{l}\text { Technoloy } \\
\text { used }\end{array}$ & $\begin{array}{l}\text { In general, they use 'out } \\
\text { of date' machines or } \\
\text { manually and do not } \\
\text { utilize ICT }\end{array}$ & $\begin{array}{c}\text { Many use machines and } \\
\text { utilize ICT }\end{array}$ & $\begin{array}{l}\text { Degree of modern } \\
\text { technology used is much } \\
\text { higher and all utilize ICT. }\end{array}$ \\
\hline
\end{tabular}

Source: Tambunan (2017), dan BI dan LPPI (2015). 
and SMEs (Menegkop \& UKM) for the period 1997-2017 shows that the number of MSMEs in Indonesia increased every year from 39.765 million MSMEs (or about 99.8 per cent of the total business units in Indonesia) in 1997 to more than 59 million units by 2017 (Figure 1). Except in 1998, when the Asian financial crisis occurred during the period 1997-98 hit Indonesia, the number of MSMEs grew negatively by more than 7 per cent, and after that in 1999 as the national economy started to recover MLSEs also recovered with a positive growth rate of almost 3 per cent (Figure 2). Most MSMEs that were out of business during the crisis period were heavily dependent on imported raw materials which became very expensive in rupiah due to the weakening of the rupiah against the US dollar by more than 500 per cent in mid-1998, while domestic demand for their products declined due to rising inflation. Many also stopped operating because of the difficulty of in getting credit due to the banking crisis as the direct result of the Asian financial crisis. In addition, there were also many MSMEs which had production linkages with LEs through subcontracting arrangements forced to stop because there was no order anymore from the LES.

One interesting thing from the Indonesian data of MSMEs is that the number of MIES dominates the number of Indonesian MSMEs which is about 99 per cent. However, the distribution of MSMEs under this subgroup is not the hallmark of Indonesian MSMEs. For instance, based on data from the APEC Secretariat, as can be seen in Figure 3, in other both developing and developed economies in the Asia-Pacific region, the share of MIEs in total MSMEs is also large, above 50 per cent. Nevertheless, MIE's share in total MSMEs in Indonesia is the highest, followed by Canada in second position (98 percent). However, there are differences between MIEs in Indonesia or in other developing economies in the region such as Thailand, Cambodia, Vietnam and China with those in, for example, the US, Japan, Australia and South Korea. In the first group of economies MIEs are generally traditional business units with very low degree of mechanization (see again Table I), whereas in the second group of economies they are much more modern with high degree of computerization and internet usage.

Data based on the National Economic Census 2016 show that the majority of MSMEs in Indonesia are located in Java, the most populated island where also the concentration of economic activities, particularly manufacturing industry, trade, finance, construction, agriculture and services. Most of the existing firms in nonagricultural businesses in Indonesia are also found in Java which reached 16.2 million units. They are dominated by MSEs that reached 15.9 million units or nearly 61 per cent of all nonagricultural MSEs throughout the country (Table II). The majority of MEs and LEs (or MLES) in all non-agricultural sectors are also found in Java that reached 291.7 thousand units or 65.2 per cent of total non-agricultural MLEs in Indonesia. Meanwhile, in Papua and Maluku, the least developed region of the country, the number of non-agricultural businesses is very low, which consists of 451.9 thousand MSEs and 7.5 thousand MLEs, or only about, respectively, 1.8 per cent and 1.7 per cent of total non-agricultural business in the country.

Finally, with respect to the formation of gross domestic product (GDP), the contribution of MSMEs is always smaller than their role in generating employment. For example, in the APEC economies, more than 90 per cent of the existing total employment opportunities are generated by MSMEs, but their output contribution to GDP is below 90 per cent; although the ratio varies by economy (Yuhua 2013). This is also evident in Indonesia, where MSMEs accounted for only 


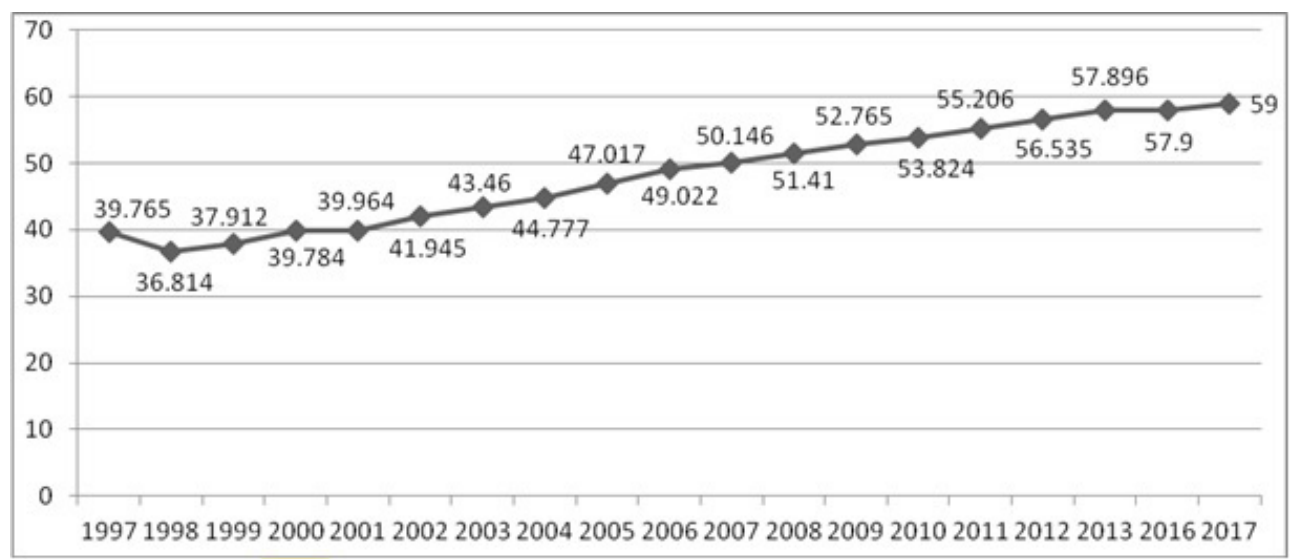

Figure 1. Total number of MSMES in all sectors, 19972017 (million units).

Table II. Distribution of MSEs and MLEs by island, 2016 (\%).

\begin{tabular}{|c|c|c|}
\hline Island & MSEs & MLEs \\
\hline Java & 60.7 & 65.2 \\
\hline Sumatera & 18.6 & 16.6 \\
\hline Sulawesi & 8.1 & 5.6 \\
\hline Kalimantan & 5.1 & 6.0 \\
\hline Bali \& Nusa Tenggara & 5.7 & 4.9 \\
\hline Papua \& Maluku & 1.8 & 1.7 \\
\hline Total & 100.0 & 100.0 \\
\hline
\end{tabular}

Source: BPS (2017).

around 60 per cent of GDP in 2013. The lower contribution of MSMEs to the formation of GDP compared to their role in job creation is caused by many things, including the limitations of advanced technology, capital and human resource that made the level of productivity per unit of MSME much lower than that in LES. Although the MSMEs' share of GDP is greater than that of the LES, it is simply because their number of units is far more than the number of companies from the LE category.

\section{Utilization of internet}

\section{Findings from the literature}

As the competition faced by MSMEs increasingly tight, it is vital for these enterprises to use modern technologies, including ICT as among their sources of competitive advantages. There are many indications from various sources that in the past decade more and more MSMEs are utilizing ICT or adopting e-commerce; although still many more MSMEs, especially MIEs, which do not/have not (yet) utilized this technology in running their business activities for various reasons. In accordance with this development, internet use, especially e-commerce, among these enterprises has recently become a popular topic for researchers not only in the fields of MSMEs but also in such as electronic business, information management, information systems and entrepreneurship; though research investigating on the adoption of e-commerce by MSMEs is still small in number. Most studies especially in the context of developing countries adopted descriptive survey research design in which random sampling techniques are used, and the data was analyzed using descriptive statistics. Some of these studies also made a good summary of the findings from previous studies. There are three key issues that have received a great attention from these existing studies, namely (i) factors that influence the decision of MSMEs or their main constraints to utilize ICT, (ii) companies or entrepreneurs' motivation or reasons to utilize ICT or to adopt e-commerce, and (iii) the benefit of utilizing 
ICT and applications to support their business activities. Table III summarizes the findings of selected important studies in the past two decades.

\section{Findings from Indonesian secondary data}

In Indonesia, despite the rapidly growing internet media, the number and percentage of MSEs that have utilized the internet is still very low. According to the 2016 Economic Census, only as many as 563 thousand enterprises or about 2.14 per cent of total MSEs in Indonesia which have utilized the internet media for their business activities. Until know there are very few published papers or reports, either based on field surveys or observations, on the utilization of ICT by MSMEs in Indonesia that can explain why the use of internet by MSEs in the country is still very low. According to Julianto (2016), there are various obstacles faced by the Indonesian government (the State Ministry of Cooperative and Small Medium Enterprise) in encouraging MSES owners to utilize ICT, which include their low understanding of this kind of technology, their mindset which is not in favor of using internet in doing their businesses, and their lack of knowledge on how to operate this technology. Meanwhile, according to a report issued by the Indonesian Ministry of Industry, MSMEs, especially MSEs and located in rather isolated/rural areas, are generally still unfamiliar with the online marketing system. They prefer to do marketing with conventional methods, by utilizing the distribution networks that they have been using for a long time or involving many distributors who have long been their customers (Julianto 2016).

So far, there is only one study in Indonesia which was based on a survey conducted by Rahayua and Day in 2015. Target respondents for their study were owner/managers of MSMEs.
In this study, MSMEs refers to a business which has less than 100 employees, assets less that 10 billion rupiah and total sales per year below 50 billion rupiah. From various data sources, including from the Ministry of Cooperative and SME, a total of 3,267 MSMEs were chosen as sampling frame for this study and only 292 MSMEs participated in this study, a response rate of 8.9 per cent. Based on their finding, they conclude that the adoption of e-commerce by MSMEs in Indonesia is affected by several factors which are perceived benefits, technology readiness, owners' innovativeness, owners' ICT experience and owners' ICT ability. Their findings also show that the individual factors play a significant role in adopting of e-commerce technology by MSMEs in Indonesia.

The distribution of MSEs using internet by province is shownby Figure 5. As can be seen, most MSEs in this country that utilize the internet for businesses are located in Java island. Provinces in Java with the highest proportion of MSEs using the internet are East Java with around 18.72 per cent of all MSEs using internet in Indonesia, followed by West Java and Central Java with, respectively 18.11 per cent and 15.41 per cent. While outside Java island, especially in the eastern region, the percentage is much lower. Provinces that have the lowest percentage in this region is Maluku with only 0.12 per cent, North Maluku with 0.16 per cent, and West Papua 0.19 per cent.

The percentage distribution by province as shown in Figure 5 is in line with the fact that the number of MSEs in the eastern region as well as its share in national GDP is much lower than that in the western region, especially Java where the majority of these enterprises are located and it has the highest GDP share (Figure 4). So, there is a positive relationship between the magnitude of economic activities in a province relative to other provinces, reflected by its share 


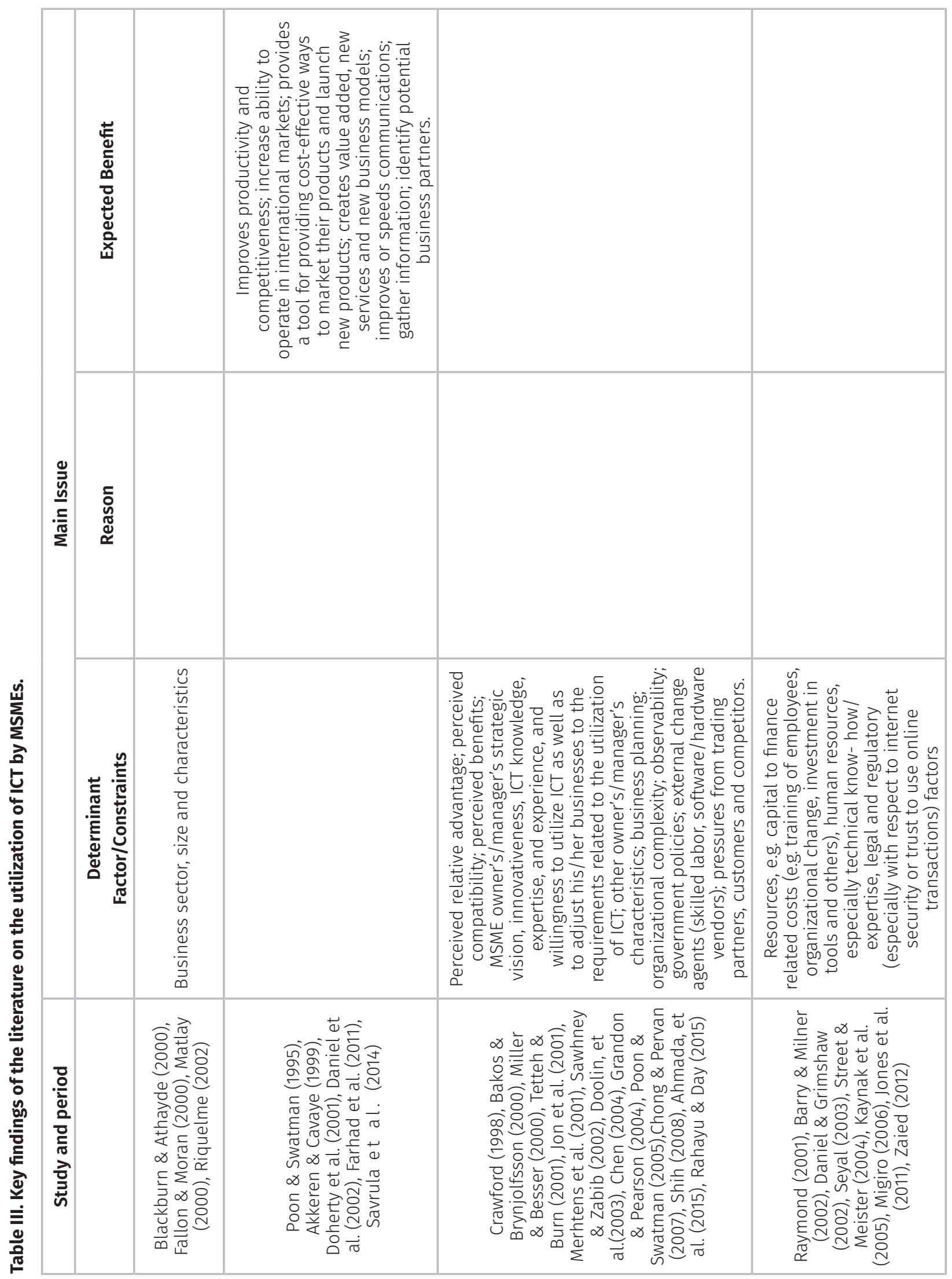




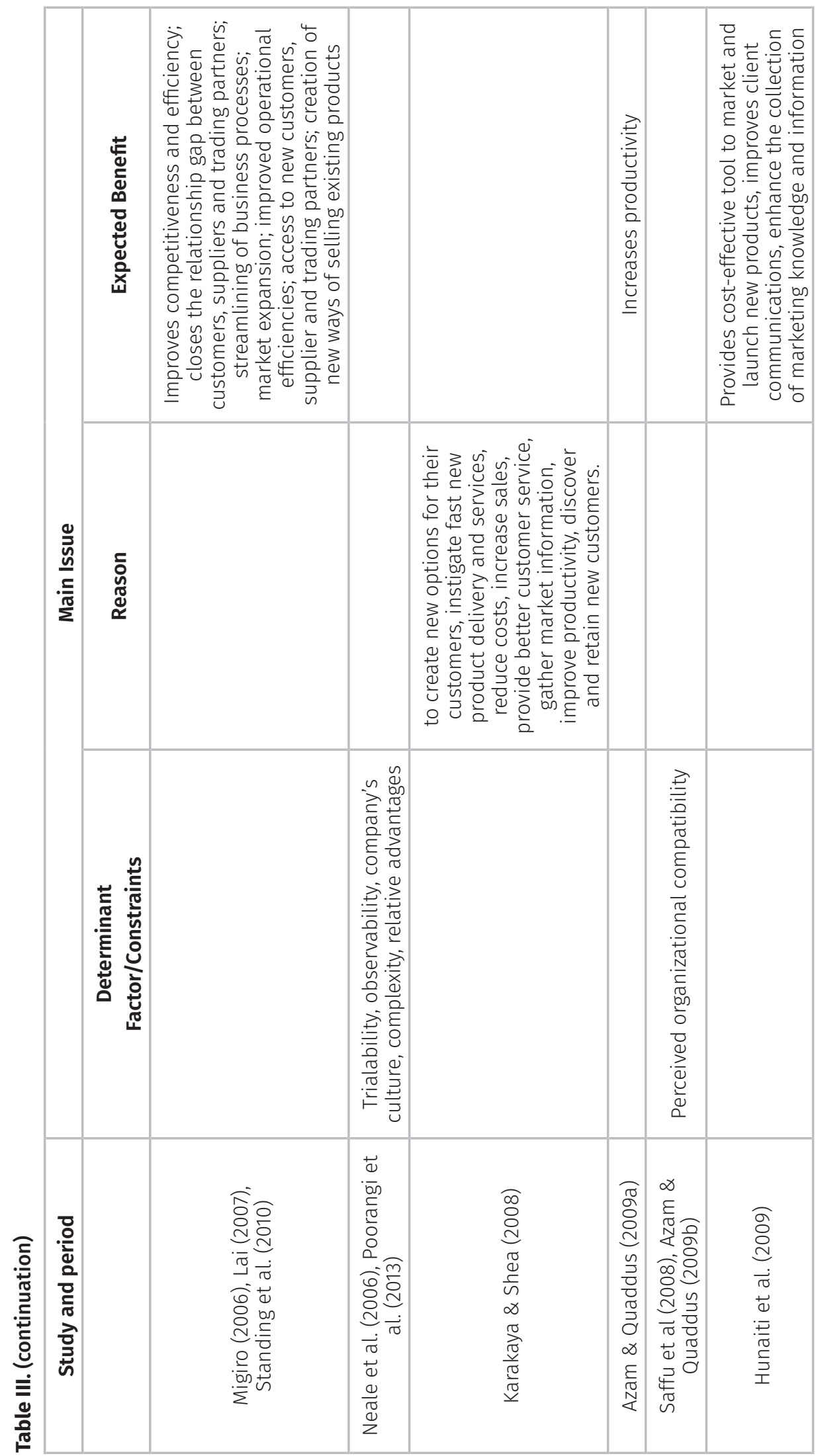



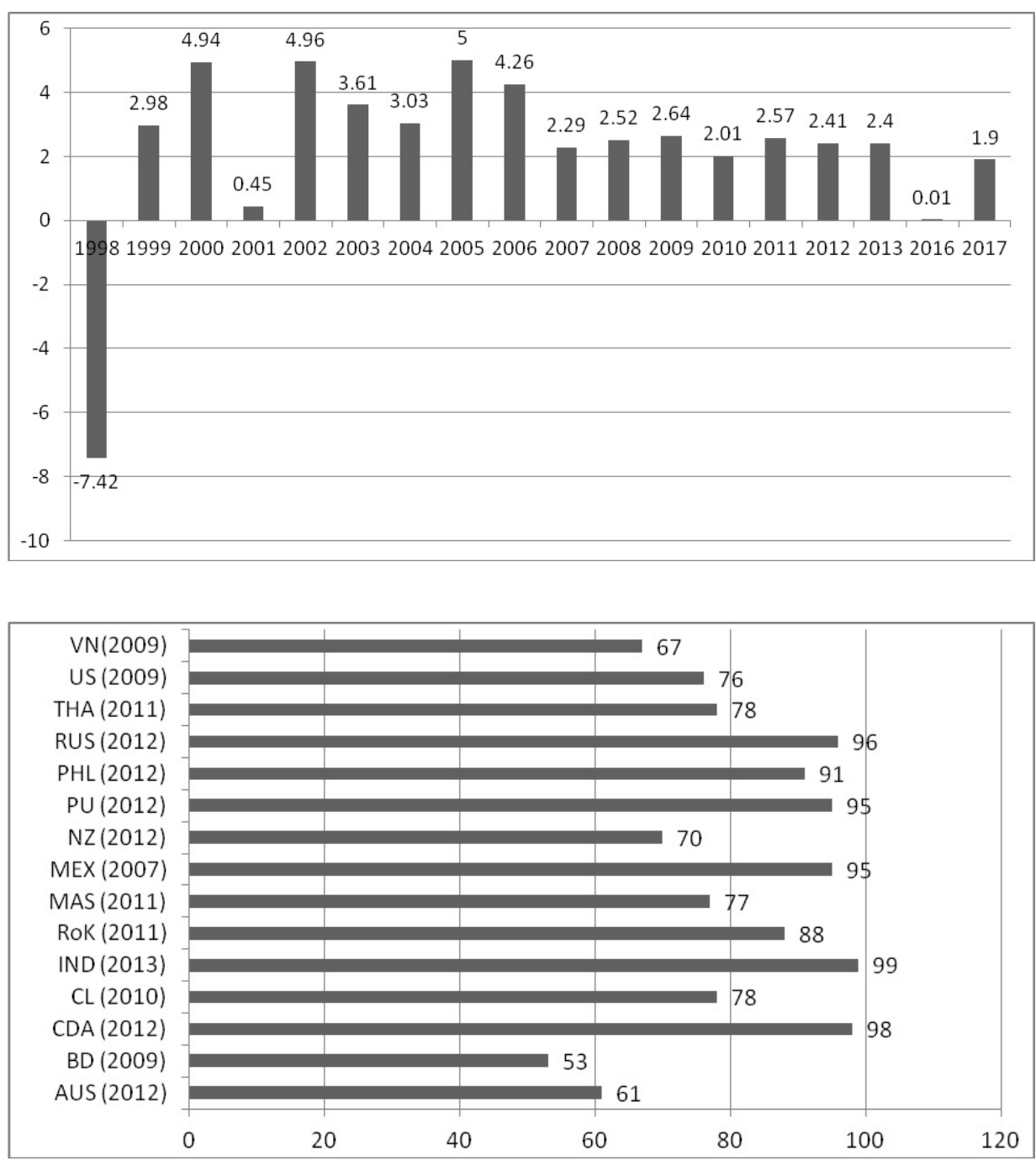

Figure 2. Growth rate of total number of MSMEs in all sectors, 1998-2017 (\%).

Figure 3. Share of MIES in total MSMEs in APEC member economies (\%) of national GDP, and the number of MSEs in the province using the internet compared to other provinces, indicated by its share of Indonesia's total MSEs in utilizing the internet (Figure 6).

Figure 5 does not, however, show the difference between provinces in the intensity of the internet usage by MSEs. For this, Figure 7 shows the percentage of total MSEs that use the internet per province. For instance, in Java, the province with the highest percentage of MSES that use the internet is D.I Yogyakarta with near to 6 per cent. In the second place is DKI Jakarta, the Capital city of Indonesia, with almost 4 per cent. In some provinces outside Java the internet usage rate of MSEs is also quite high, such as in Kep. Riau, Bali, and East Kalimantan, with almost 4 per cent of total MSEs in these provinces are using the internet. Here too, by combining the data in Figure 7 with data on total income and population per province, the intensity of the internet usage by MSEs is found to have a positive relationship with the level of income per capita (Figure 8).

of course, not only factors such as income per capita, level of economic development, technical skills of workers, ICT knowledge and experience of MSE owners/managers, security, and ICT infrastructure are very influential on 


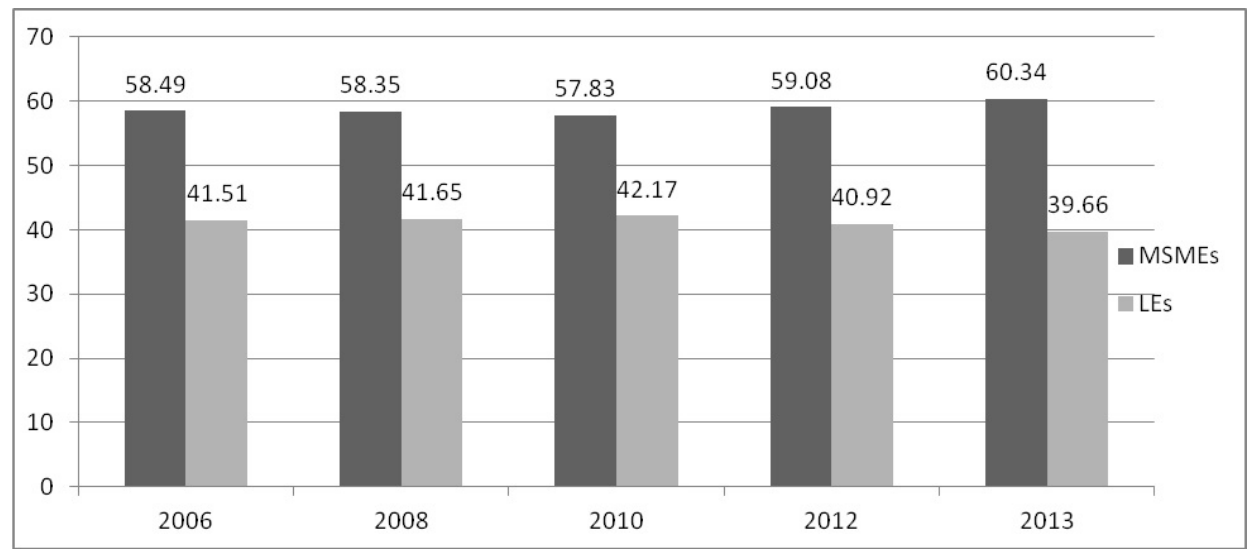

Figure 4. GDP shares of MSMEs and LES, 2006-2013 (\%).

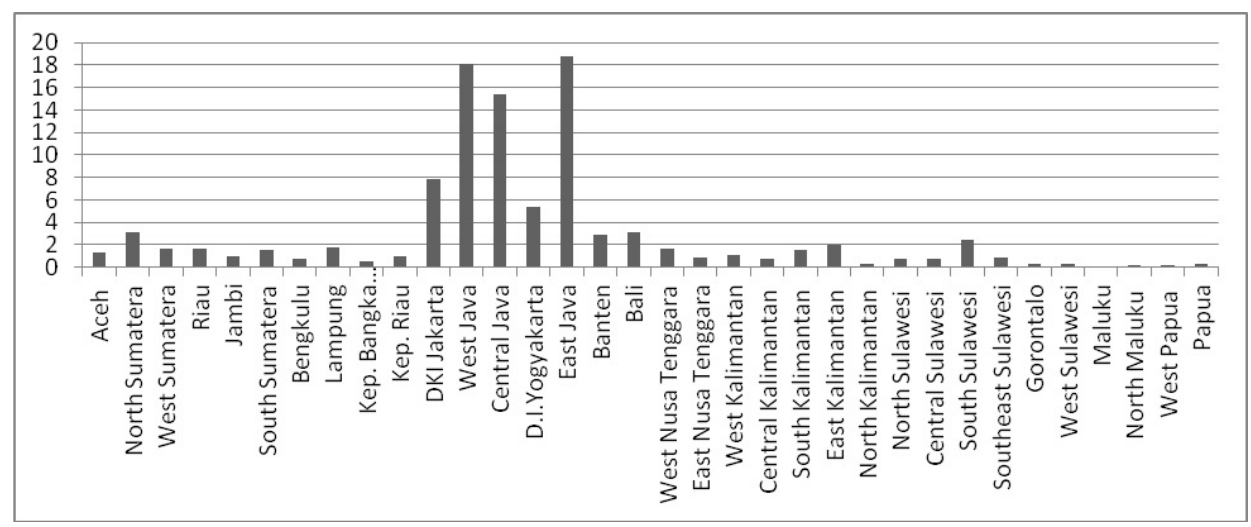

Figure 5. Percentage distribution of total MSEs using internet by province, Indonesia, 2016.

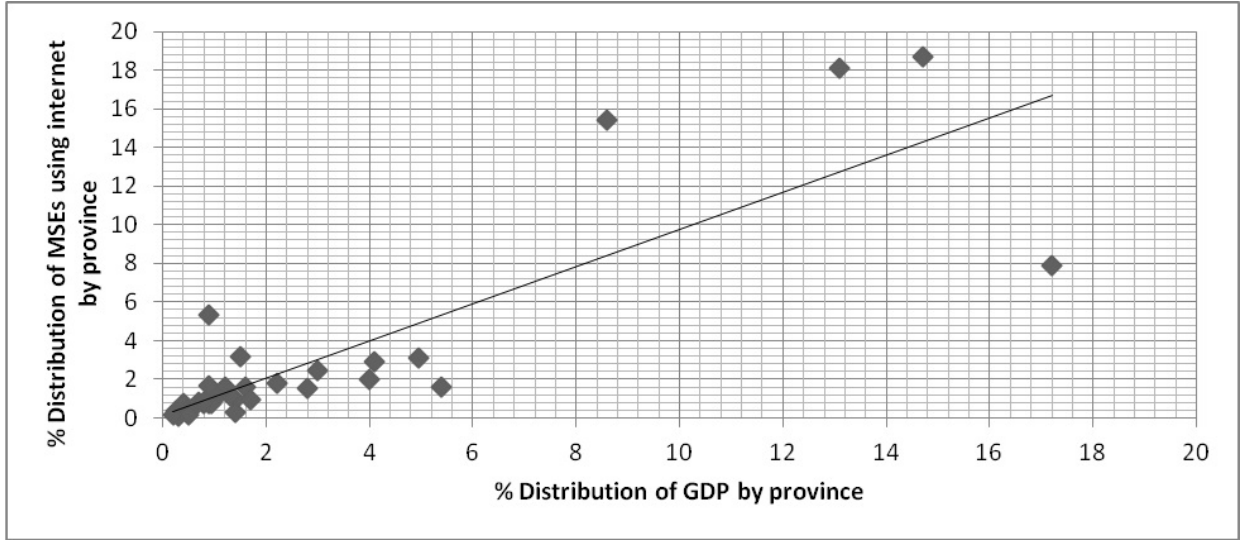

Figure 6. Percentage of MSEs using internet and GDP by province, Indonesia, 2016.

the managers or business owners to use the internet in running their businesses, but the type of business is also very important. Or even it is more important than those factors because today there are many types of businesses that must use the internet or really require online transactions or the advantages of using the internet are felt directly by the company (e.g. very low cost promotion activities). The types of businesses that fall into this category include travel agencies, hotels, rental services, bookstores, fashion, and online transport.

The 2016 Economic Census shows that the types of businesses that most MSEs utilize the internet are retail trade and car and motorcycle repair and care services with around 39.64 per 

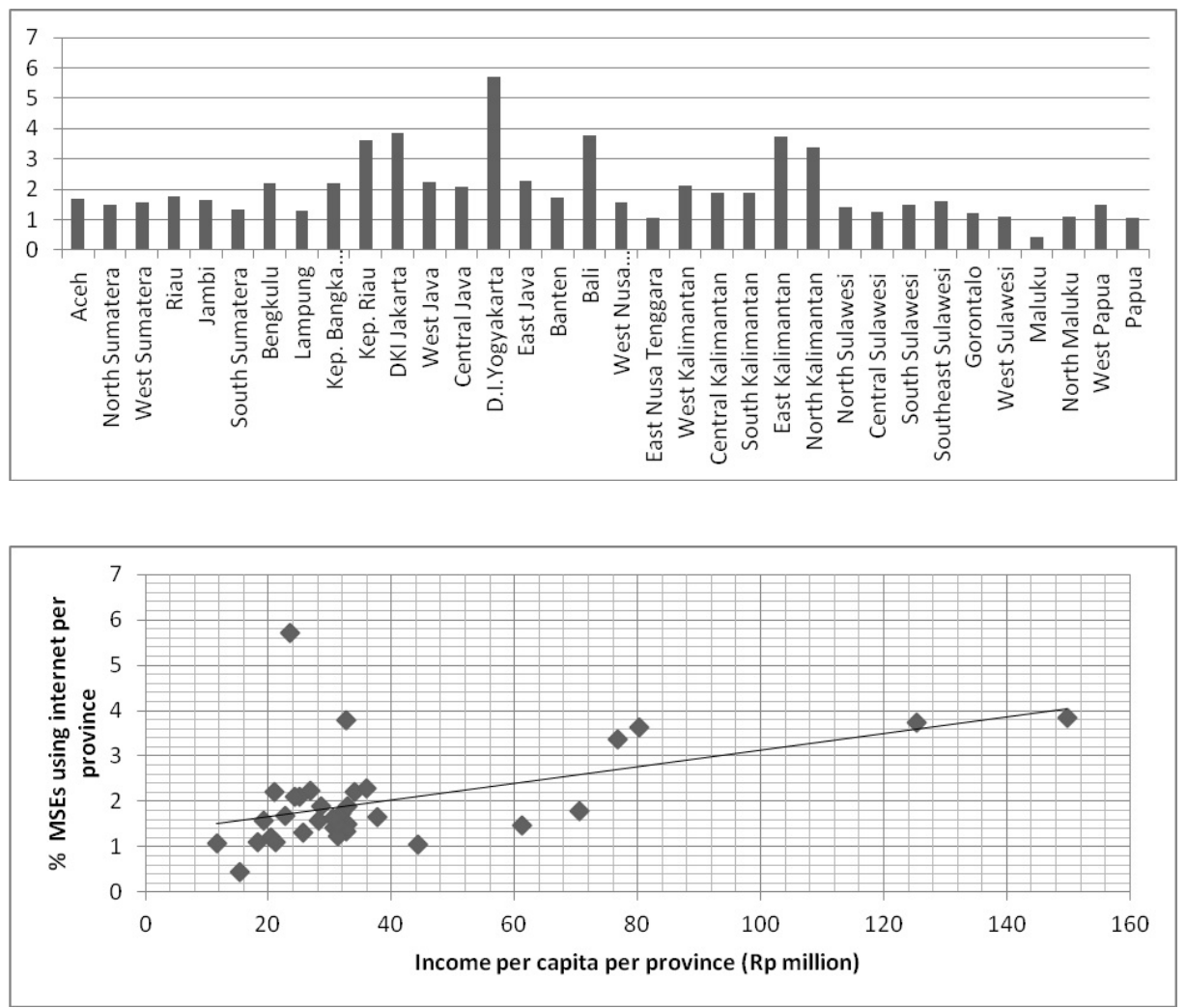

Figure 7. Percentage of MSEs using internet per province, Indonesia, 2016.

\section{Figure 8. Percentage of MSEs using internet and income per capita per province, Indonesia, 2016.}

cent (Figure 9). Especially in the retail trade, the use of online transactions by both consumers (buying) and producers (selling) in Indonesia has grown tremendously in recent years. This development is also encouraging or even forcing more and more MSEs in this sector to utilize the internet, both in the form of using existing marketing websites and creating their own websites. Other types of businesses that are also run by many MSEs by utilizing the internet are information and communication with 11.73 per cent, manufacturing industry with 10.66 per cent, and education with 8.09 per cent. Meanwhile, the least types of businesses carried out by MSEs that utilize internet are real estate business and human health and social activities. Only about 0.56 per cent of total MSEs in the real estate sector that utilize the internet, and in the human health and social activities it is only 1.30 per cent. The low percentages actually do not show low internet utilization rates of MSEs in these two sectors but mainly because the low number of MSEs in these both categories of businesses, especially when compared to the number of MSEs in the trade sector.

Finally, Figure 10 gives an overview of turnover obtained by MSEs that utilize internet for business and those which do not use the internet. As can be seen, in general, for both categories of MSEs, most have a turnover of less than 300 million rupiah, namely a total of 79.41 per cent for MSEs that utilizes internet for business and 91.51 per cent for those not utilizing internet. This is also in line with the fact that due to their small size, most MSEs in Indonesia have turnover per year below Rp 300 million. When viewed from the percentage of MSEs with turnover more than 300 million rupiah, more than 20 per cent or about one in five MSEs which utilizes the internet for business has a turnover 


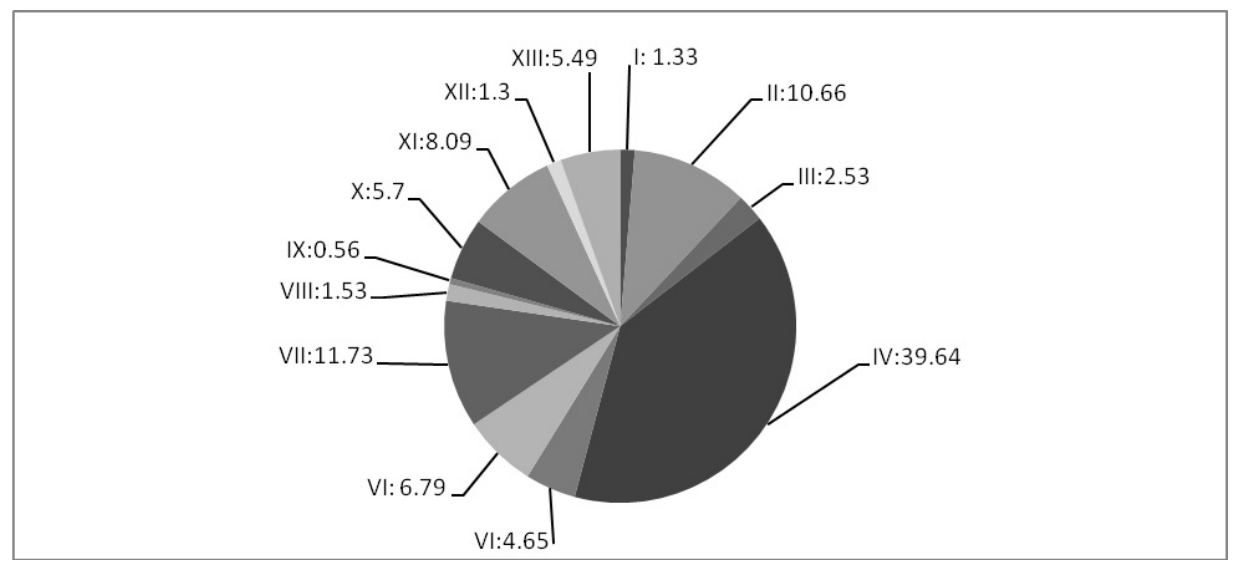

Figure 9. Distribution of MSEs using internet by type of business, 2016.

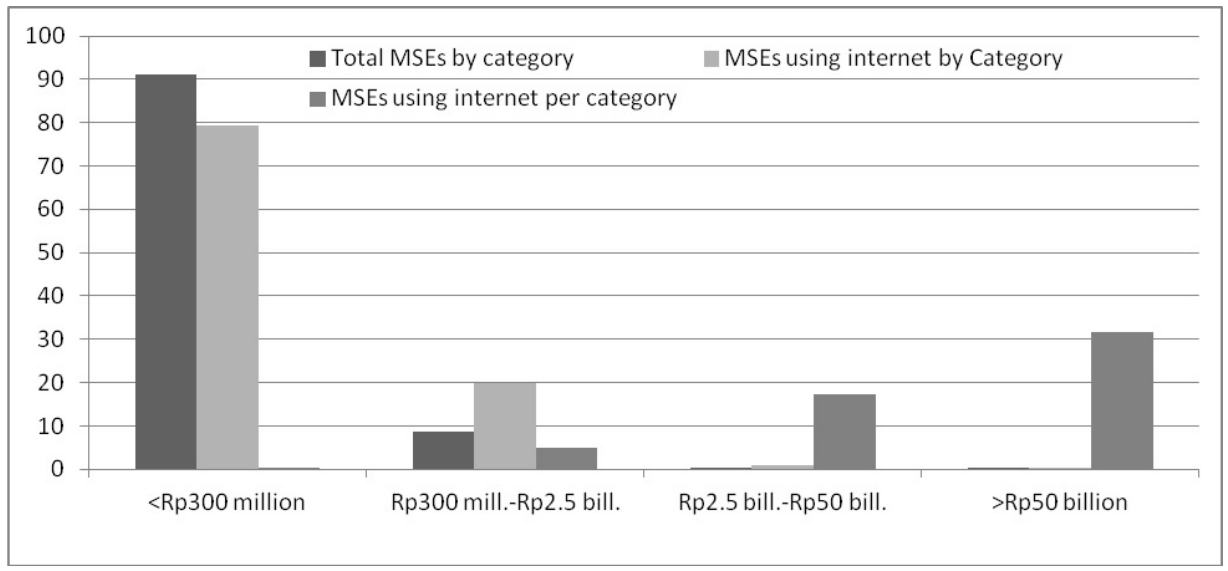

Figure 10. Total MSEs, MSEs using internet and category of revenues, Indonesia, 2016.

above 300 million rupiah. On the other hand, MSEs that do not utilize internet for business, the percentage of MSE which has a turnover above 300 million the rupiah is not more than 10 per cent. The ratio of MSEs that use the internet for business to those which do not use it in businesses with high turnover is greater than that in businesses with lower turnover.

This ure may give two different impressions. First, it could mean that businesses with a high turnover value usually have more complicated processes with higher degree of computerization, and a greater financial/investment risk than businesses with smaller turnover value. Therefore, naturally, companies including MSES in the first category of businesses are more in need of modern technologies, including ICT, than their counterparts do in the second category of businesses. Or, alternatively, it could mean that MSEs that utilize internet for businesses have a greater opportunity to generate higher turnover values compared to those that do not utilize the internet, which is in accordance with what has been said in the literature on the benefits of using the internet for MSMEs. Findings from a survey conducted by the Indonesian Ministry of Industry indicate that successful MSMEs doing online marketing gain far greater profits than ever before (Julianto 2016).

\section{CONCLUSIONS}

This study reveals several key facts. First, MSMEs are of overwhelming importance to Indonesia's local economy, accounting for more than 99 percent of all firms, and the majority 
of MSMES are MSEs. Second, the use of internet by MSEs in the country is still very low. Very few existing studies reveal several explanations, which include their low understanding of the importance of ICT for their businesses, their mindset which is not in favor of using ICT in doing their businesses (e.g. they prefer to do marketing with conventional methods), their lack of knowledge on how to operate this technology, and lack of owners' innovativeness. Third, there is a positive relationship between the magnitude of economic activities in a province relative to other provinces and the number of MSEs in the province using the internet compared to other provinces. Fourth, the intensity of the internet usage by MSEs is found to have a positive relationship with the level of income per capita. Fifth, the type of business is also important in encouraging MSEs to utilize internet. The types of businesses that most MSEs utilize the internet are retail trade and car and motorcycle repair and care services. Sixth, MSEs in types of businesses with more complicated processes and have a greater financial risk but on the other hand have a high turnover value are more likely to utilize internet than those in types of businesses with less degree of computerization / automation and low investment risk but also small turnover value.

Finally, the information in this article is also important for policy makers not only in Indonesia but also other developing countries, for two main reasons. First, with their huge number (which is significant larger than the number of large enterprises), MSMEs are indeed very important not only as a source of employment, but, potentially, as a growth engine for the economy. This means that that capacity building, including their ability or readiness to utilize ICT, in these enterprises should be given a high priority by the policy makers in their economic development policies. Second, MSMEs are a good starting place for the development of women entrepreneurs. This means that these enterprises do have an important role to play in promoting women empowerment in developing countries, which in these days is among important targets of the sustainable development goals (SDGs).

\section{REFERENCES}

AHMADA SZ, ABDUL RAB, TENGKU MF \& KHAIRUL AMZ. 2015. An Empirical Study of Factors Affecting e-Commerce Adoption among Small- and Medium-Sized Enterprises in a Developing Country: Evidence from Malaysia. Inf Technol Dev 21(4): 555-572

AKKEREN J \& CAVAYE A. 1999. Factors affecting the adoption of e-commerce technologies by small business in Australia - an empirical study. In: The $10^{\text {th }}$ Australian Conference On Information System, 1-3 December, Wellington.

AZAM MS \& QUADDUS M. 2009a. Adoption of b2b e-commerce by the SMEs in Bangladesh: an empirical analysis. In: The Asian Business Research Conference, 11-12 April, Dhaka.

AZAM MS \& QUADDUS M. 2009b. Adoption of e-commerce by the SMEs in Bangladesh: the effects of innovation characteristics and perceived risk. In: The Australian And New Zealand Marketing Academy Conference, 30 November - 2 December 2009, Melbourne, Victoria.

BAKOS Y \& BRYNJOLFSSON E. 2000. Bundling and Competition on the internet. Mark Sci 19(1): 63-82.

BARRY H \& MILNER B. 2002. SME'S and Electronic Commerce: A Departure from the Traditional Prioritisation of Training? J Eur Ind Train 25(7): 316-326.

BLACKBURN R \& ATHAYDE R. 2000. Making the connection: the effectiveness of internet training in small businesses. Educ Train 42(4/5): 289-299.

BPS. 2017. Analisa Ketenagakerjaan Usaha Mikro Kecil. Sensus Ekonomi 2016. Analisa Hasil Listing, November, Jakarta: Badan Pusat Statistik Nasional.

CHEN S. 2004. Adoption of electronic commerce by SMES of Taiwan. Int J Electron Commer Stud 2(1): 19-34.

CHONG S \& PERVAN G. 2007. Factors Influencing the Extent of Deployment of Electronic Commerce for Small and Medium Sized Enterprises. JECO 5(1): 1-29. 
CRAWFORD J. 1998. NEWS -A Project to get smaller enterprises online. The National Office for the Information Economy (NOIE), Canberra. https://www. finance.gov.au/agimo-archive/publications_noie/1998. html. (accessed 10 January 2017).

DANIEL EM \& GRIMSHAW DJ. 2002. An exploratory comparison of electronic commerce adoption in large and small enterprises. J Inf Technol 17(3): 133-147.

DANIEL E, WILSON H \& MYERS A. 2002. Adoption of e-commerce by SME'S in the UK: towards a stage model. Int Small Bus J 20(3): 253-268.

DOHERTY N, HUGHES F \& ELLIS-CHADWICK F. 2001. An investigation into the factors affecting the level of e-commerce uptake amongst SMEs. In: Roberts $M$ et al. (Eds), Sixth Annual Conference of UKAIS, Cambridge, MA: School Press, p. 251-257.

DOOLIN B, MCLEOD L, MCQUEEN B \& WATTON M. 2003. Internet strategies for establishing retailers: Four New Zealand case studies. JITCA 5(4): 3-19.

FALLON M \& MORAN P. 2000. Information Communications Technology (ICT) and manufacturing SMEs. In: The 2000 Small Business and Enterprise Development Conference, 10-11 April, University of Manchester, Manchester.

FARHAD N, BEHRAVESH M \& RASOULI R. 2011. Developing Countries and Electronic Commerce the Case of SMES. World Appl Sci J 15(5): 756-764.

GRANDON EE \& PEARSON JM. 2004. Electronic commerce adoption: an empirical study of small and medium US Business. Inf Manag 42: 197-216.

HUNATI Z, MASA'DEH R, MANSOUR M \& AL-NAWAFLEH A. 2009. Electronic commerce adoption barriers in small and medium-sized enterprises (SMEs) in developing countries: the case of Libya. IBIMABR 2: 37-45.

JON K, LAI TL, HUI CK, DENNIS NCH \& MENG TS. 2001. Electronic commerce adoption by SMEs in Singapore. In: The $34^{\text {th }}$ Annual Hawaii International Conference on System Sciences, January 3-6, Maui, Hawaii.

JONES P, PACKHAM G, BEYNON-DAVIES P \& PICKERNELL D. 2011. False promises: E-business deployment in Wales' SME community. JSIT 13(2): 163-178.

JULIANTO PA. 2016. Pemerintah Targetkan 44 Juta UMKM Pasarkan Produk Lewat Internet. Kompas Newspaper, 18 June. http://ekonomi.kompas.com/read/2016/06/18/ 111218426/pemerintah.targetkan. 44.juta. umkm.pasarkan. produk.lewat.internet. (accessed 24 November 2017).

KARAKAYA F \& SHEA T. 2008. Underlying Motivations for Establishing E-Commerce Business and Their
Relationship to E-Commerce Success. J Internet Commer 7(2): 153-179.

KAYNAK E, TATOGLU E \& KULA V. 2005. An analysis of the factors affecting the adoption of electronic commerce by SMEs Evidence from an emerging market. Int Mark Rev 22(6): 623-640.

LAI IKW. 2007. The strategic changes by adopting internetbased interorganizational systems. Manag Res News 30(7): 495-509.

MATLAY H. 2000. Training in the Small Business Sector of the British Economy. In: Carter S and Jones D (Eds), Enterprise and Small Business: Principles, Policy and Practice, Addison Wesley Longman, London. p. 140-149.

MEHRTENS J, CRAGG PB \& MILLS AM. 2001. A Model of Internet Adoption by SMEs. Inf Manag 39: 165-176.

MIGIRO SO. 2006. Diffusion of ICTS and E-commerce adoption in manufacturing SMEs in Kenya. SA Jnl Libs \& Info Sci 72(1): 35-44.

MILLER NL \& BESSER TL. 2000. The Importance of Community Values in Small Business Strategy Formation: Evidence from Rural lowa. J Small Bus Manag 38(1): 68-85.

NEALE J, MURPHY J \& SCHARL A. 2006. Comparing the Diffusion of Online Service Recovery in Small and Large Organizations. J Mark Commun 12(3): 165-181.

POON S \& SWATMAN P. 1995. The Internet for small businesses: An enabling infrastructure for competitiveness. In: The 1995 International Networking Conference, 27-30 June, Honolulu, Hawaii

POON S \& SWATMAN P. 2005. Small business use of the Internet: Findings from Australian case studies. Int Mark Rev 14(5): 1-15.

POORANGI MM, EDWARD WSK, NIKOONEJAD S \& KARDEVANI A. 2013. E-commerce adoption in Malaysian Small and Medium Enterprises Practitioner Firms: A revisit on Rogers' model. An Acad Bras Cienc 85: 1593-1604.

RAHAYU R \& DAY J. 2015. Determinant Factors of E-commerce Adoption by SMEs in Developing Country: Evidence from Indonesia. Procedia Soc Behav Sci 195: 142-150.

RAYMOND L. 2001. Determinants of Web Site Implementation in Small Business. Internet Res 11(5): 411-422.

RIQUELME H. 2002. Commercial Internet Adoption in China: Comparing the Experience of Small, Medium and Large Business. Internet Res 12(3): 276-286.

SAFFU K, WALKER JH \& HINSON R. 2008. Strategic value and electronic commerce adoption among small and 
medium-sized enterprises in a transitional economy. J Bus Ind Mark 23(6): 395-404.

SAVRULA M, INCEKARAB A \& SENERB S. 2014. The Potential of E-commerce for SMEs in a Globalizing Business Environment. Procedia Soc Behav Sci 150: 35-45.

SAWHNEY M \& ZABIB J. 2002. Managing and Measuring Relational Equity in the Network Economy. J Acad Mark Sci 30(4): 313-332.

SEYAL AH. 2003. An Investigation of E-Commerce Adoption in Micro Business Enterprises: Bruneian Evidence. In: The $4^{\text {th }}$ International Conference On Working With E-Business (We-B 03), 24-25 November, Perth.

SHIH H. 2008. Contagion effects of electronic commerce diffusion: Perspective from network analysis of industrial structure. Technol Forecast Soc Change 75(1): 78-90.

STANDING S, STANDING C \& LOVE P. 2010. A review of research on e-marketplaces 1997-2008. Decis Support Syst 49(1): 41-51.

STREET CT \& MEISTER DB. 2004. Small business growth and internal transparency: The role of information systems. MIS Quart 28(3): 473-506.

TETTEH E \& BURN J. 2001. Global Strategies for SMEbusiness: Applying the SMALL Framework. Logist Inf Manag 14: 171-180.

YUHUA BZ. 2013. SMEs in the APEC Region. APEC Policy Support Unit, Policy Brief No.8, 3 December, Singapore: APEC Secretariat.

ZAIED ANH. 2012. Barriers to E-Commerce Adoption in Egyptian SMES. IJIEEB 3: 9-18.

\section{How to cite}

TAMBUNAN TTH. 2020. Evidence on the use of internet for businesses by MSEs in a Developing Country. The Indonesian case. An Acad Bras Cienc 92: e20180555. DOI 10.1590/0001-3765202020180555.

Manuscript received on June 2, 2018; accepted for publication on January 18, 2019

\section{TULUS T.H. TAMBUNAN}

https://orcid.org/0000-0003-4526-3042

Center for Industry, SME \& Business Competition

Studies, University of Trisakti, Jakarta, Indonesia

E-mail: ttambunan56@yahoo.com

\section{(cc) BY}

